\title{
MANAJAMEN RISIKO KESELAMATAN DAN KESEHATAN KERJA (K3) PROYEK PEMBANGUNAN JALUR GANDA KERETA API
}

\author{
Aswan Munang ${ }^{1}$, Faisal RM², Agus Mansur ${ }^{3}$ \\ Program Studi Teknik Industri, fakultas Teknologi Industri dan Informatika \\ Institut Teknologi Telkom Purwokerto \\ D.I Panjahitan No.128 Purwokerto, Jawa Tengah \\ aswan@ittelkom-pwt.ac.id¹, 845210101@staf.uii.ac.id², agusmansur.am@gmail.com³
}

\begin{abstract}
PT. $X Y Z$ is a contractor company that focused on railway installation. Nowadays, PT.XYZ is working on a double track railway development in Semarang-Bojonegoro section. The project requires the ability of a project manager to manage risk. Working accidents occur due to poor risk management. The purpose of risk management is to anticipate the occurrence of risks that has caused financial losses and failure. The objectives of the study are to implement risk assessment and risk control based on risk management standards. The risk management process that has been applied refers ISO 31000 standards. The standards are included the risk identification, risk analysis and risk evaluation. The result shows that assessing railway double rail project has identified 19 unexpected risks as a high risk and 12 unacceptable risks that are required risk mitigation to reduce the impact.
\end{abstract}

Keyword: Project Management, Risk Management, Risk Mitigation.

\begin{abstract}
Abstrak
PT. XYZ adalah perusahaan kontraktor dibidang pembangunan jalur kereta api. Proyek pembangunan jalur ganda kereta api memerlukan kemampuan seorang manajer proyek dalam mengelola manajemen risiko. Kecelakaan kerja yang terjadi disebabkan belum terkelolanya manajemen risiko dengan baik. Pengelolaan manajemen risiko sangatlah penting dapat mengantisipasi terjdinya risiko yang menimbulkan kerugian finansial dan kegagalan dalam mencapai tujuan proyek. Tujuan penelitian melakukan penilaian dan pengendalian risiko dengan menggunakan standar manajemen risiko. Proses manajemen risiko mengunakan standar ISO 31000 meliputi tahapan identifikasi, analisis dan evaluasi risiko. Hasil penelitian menunjukkan bahwa pembangunan proyek jalur ganda kereta api memiliki risiko yang tinggi karena langsung bersinggungan dengan jalur kereta aktif sehingga teridentifikasi ada 19 risiko yang tidak diharapkan. Selain itu terdapat 12 risiko yang tidak dapat diterima. Risiko yang tidak dapat diterima memerlukan mitigasi risiko mengurangi dampak yang ditimbulkan.
\end{abstract}

Keyword: Manajemen Proyek, Manajemen risiko, Mitigasi Risiko. 


\section{Applied Industrial Engineering Journal}

Vol.02, No. 01, Juni 2018, pp. 08 15

ISSN 2614-235X (Printed)

ISSN 2615-3033 (Online)

http://publikasi.dinus.ac.id/index.php/aiej/index

\section{Pendahuluan}

Proyek konstruksi melibatkan banyak bidang disiplin ilmu. Proyek merupakan suatu kegiatan yang berlangsung dalam waktu terbatas, dengan alokasi dana tertentu dan dimaksudkan untuk menghasilkan produk dan deliverable yang mutunya sudah digariskan dengan jelas (Suharto, 1988). Menajemen risiko merupakan pendekan yang digunakan untuk mengantisipasi risiko yang terjadi. Proyek kereta api dicirikan oleh operasional skala besar, teknologi moderen, struktur kompleks, standar teknis dan kualitas tinggi, durasi panjang, dan unit kolaboratif. Keselamatan dan kesehatan kerja (K3) merupakan standarisai utama keselamatan pelaksanaan pekerjaan konstruksi karena merupakan bagian dari perencanaan dan pengendalian proyek. Proses manajemen risiko proyek merupakan suatu rangkaian praktik yang rasional yang diambil oleh para pengambil keputusan untuk menjaga pelaksanaan proyek berjalan sesuai tujuan. Bagaimana pengelolaan manajemen risiko pembangunan proyek jalur ganda kereta api untuk mempertimbangkan risiko-risiko yang terjadi. Kecelakan kerja yang terjadi sangat memepengaruhi proses pelaksanaan proyek jalur ganda kereta api dan jika risiko tidak dicegah secara efektif, sehingga dapat menghambat realisasi dari tujuan, biaya, waktu dan kualitas.

Kecelakaan kerja dalam pelaksanaan proyek menunjukan bahwa pengelolaan proyek belum/tidak sesuai dengan perencanaan, pengawasan yang matang dan bertanggung jawab. Penilaian risiko merupakan langkah yang sangat baik dan mempermudahkan perusahaan dalam mengindentifikasi faktor-faktor risiko. Risiko dalam pekerjaan konstruksi tidak hanya sebatas faktor ekonomi (pendanaan) tetapi faktor alam, faktor manusia, faktor politik, dan faktor lingkungan. Manajemen risiko dalam proyek - proyek konstruksi masih belum terkelola dengan baik di sebabkan kurangnya pengetahuan dan manfaat dalam pelaksanan proyek [1]. Manajemen risiko berpengaruh sangat penting dalam mengelola waktu pelaksanan proyek konstruksi untuk menghindari kerugian biaya, mutu, jadwal penyelesaian proyek dan denda yang memaksa [2]. Penjadwalan proyek ketat, variasi desain, prosedur perizinan administratif yang berlebih, perencanaan yang tidak sesuai merupakan risiko yang banyak terjadi di proyek kontruksi [3]. Keterlambatan pelaksanaan proyek terjadi karena kurannya mengantisipasi kecelakan kerja yang terjadi. Para pelaku dalam industri konstruksi sekarang ini menyadari akan pentingnya memperhatikan permasalahan risiko pada proyek-proyek yang ditangani, karena kesalahan dalam memperkirakan dan menangani risiko akan menimbulkan dampak negatif, baik langsung maupun tidak langsung pada proyek konstruksi.

Hasil penelitian memungkinkan kontraktor meningkatkan dan mengembangkan fungsi manajemen risiko berdasar pengalaman pelaksanaan proyek pembangunan jalur ganda kereta api. Pengelolaan manajemen risiko yang lakukan dapat di kembangkan sebagai patokan untuk evalusai dan perbaikan. Pengembangan sistem manajemen risiko yang efektif dan efesien dalam meningkatkan keselamatan dan kesehatan kerja (K3) sehingga dapat mengetahui risiko yang mungkin akan terjadi dan memonitor akifitas-aktifitas proyek yang berpotensi menibulkan risiko kegagalan proyek.

\section{Tinjauan Pustaka}

Risiko pada proyek konstruksi bagaimanapun tidak dapat dihilangkan tetapi dapat dikurangi atau ditransfer dari satu pihak kepihak lainnya [4]. Manajemen risiko adalah semua rangkaian kegiatan yang berhubungan dengan risiko yaitu perencanaan (planning), penilaian (assessment), penanganan (handling) dan pemantauan (monitoring) risiko [5]. Manajemen risiko adalah sistem yang sistematik dari identifikasi risiko, analisis risiko dan pengendalian risiko proyek [6]. Manajemen risiko pada proyek konstruksi di pemkab jembrana ditujukan untuk mengidentifikasi risiko pada proyek konstruksi secara komprehensif dengan penelitian menggunakan deskriptif kualitatif, brainstroming wawancara dan dengan menggunakan kuisioner [7]. 


\section{Applied Industrial Engineering Journal}

Vol.02, No. 01, Juni 2018, pp. 08 15

ISSN 2614-235X (Printed)

ISSN 2615-3033 (Online)

http://publikasi.dinus.ac.id/index.php/aiej/index

\section{Metode Penelitian}

\subsection{Ruang Lingkup Penelitian}

Penelitian ini merupakan studi pada proyek pembangunan jalur ganda kereta api semarang - Bojonegoro lokasi penelitian di PT. XYZ

\subsection{Metode Penelitian}

Metode yang digunakan dalam penelitian manajemen risiko mengacu pada standar ISO 31000 dengan melakukan proses sistematis untuk mengidentifikasi risiko, menganalisis risiko dan mengevalusai risiko. Identifikasi risiko bertujuan untuk mendapatkan daftar risiko secara keseluruhan yang dapat mempengaruhi tujuan perusahaan, analisis risiko digunakan untuk mengetahui tingkat risiko dari daftar risiko yang teridentifikasi, evaluasi risiko untuk menilai potensi risiko-risiko yang sudah teridentifikasi serta melakukan tindakan mitigasi.

\section{Hasil dan Pembahasan}

\subsection{Identifikasi Risiko}

Sebelum dilakukan identifikasi risiko dengan wawancara dan brainstorming maka langkah pertama yang dibuat adalah Risk Breakdown Structure (RBS) berdasarkan tahapan pekerjan proyek sehinga dapat diketahui risiko-risiko tiap tahapan pekerjan. Indentifikasi risiko standr ISO 31000 memilki acuan pertanyaan yang dapat di gunakan dalam mengidentifikasi risiko, yaitu: (1) apa sumber risiko, (2) apakah efeknya bagi tujuan prusahaan, (3) apakah ada pengendalian yang di lakukan saat ini, (4) kapan, di mana, mengapa dan bagaimana risiko ini terjadi, (5) apa yang menyebabkan pengendalian saat ini kurang efektif. Teknik identifikasi seperti ini dinilai tepat karena peneliti tidak mempunyai pengalaman dalam merumuskan daftar risiko. Hasil dari identifikasi risiko dengan responden di dapat daftar risiko dijelaskan pada Tabel berikut:

Tabel 1. Daftar Risiko Proyek Pembangunan Jalur Ganda Kereta Api

\begin{tabular}{|c|l|}
\hline No. Risiko & Daftar Risiko Proyek Jalur Ganda Kereta Api \\
\hline & Pekerjaan Persiapan \\
\hline R1 & Gangguan komunikasi karena relokasi utilitas exsisting \\
\hline R2 & Kurangnya keamanan lingkungan kerja. \\
\hline R3 & Putusnya jaringan kabel persinyalan kereta api. \\
\hline R5 & Operator tidak mematuhi SOP dalam melakukan aktivitas proyek. \\
\hline R6 & Rusaknya peralatan pendukung keselamatan aktivitas proyek. \\
\hline & Kurangnya respon train watcher dalam mencegah kecelakaan kerja \\
\hline R7 & Pekerjaan Jalan Akses selama masa konstruksi \\
\hline R8 & Putusnya kabel optik telekomunikasi seluler. \\
\hline R9 & Kecelakaan mobilisasi material di area akses proyek. \\
\hline R10 & Kurangnya perawatan akses selama aktivitas proyek. \\
\hline R11 & Kecelakaan aktivitas proyek di lingkungan permukiman. \\
\hline R12 & Mahalnya harga sewa atau ganti rugi tanaman/tanah. \\
\hline & Pekerjaan Pendukung Teknis \\
\hline R13 & Kerusakan fasilitas umum selama aktivitas proyek. \\
\hline R14 & Hilangnya peralatan dan material proyek. \\
\hline R15 & Sulitnya sosialisasi pekerjaan proyek. \\
\hline &
\end{tabular}




\section{Applied Industrial Engineering Journal}

Vol.02, No. 01, Juni 2018, pp. 08 15

ISSN 2614-235X (Printed)

ISSN 2615-3033 (Online)

http://publikasi.dinus.ac.id/index.php/aiej/index

Lanjutan Tabel 1. Daftar Risiko Proyek Pembangunan Jalur Ganda Kereta Api

\begin{tabular}{|c|c|}
\hline & Pekerjaan Tubuh Baan dan Track \\
\hline R16 & Sulitnya prosedur perizinan aktivitas proyek. \\
\hline $\mathrm{R} 17$ & Kecelakaan mobilisasi material diperlintasan sementara (level cross). \\
\hline $\mathrm{R} 18$ & Sleeding galian tanah tubuh baan (new track/exsisting) tanah dasar tidak stabil. \\
\hline R19 & Keterlambatan pekerjaan subkontraktor. \\
\hline R20 & Keterlambatan pengiriman material proyek. \\
\hline R21 & Kegagalan pengelasan antar batang rel. \\
\hline $\mathrm{R} 22$ & Kerusakan pemasangan aksesoris (isolator,rabberpet,penambat) \\
\hline R23 & Adanya perubahan desain elevasi dan center line tubuh baan \\
\hline R24 & Kerusakan material proyek penempatan diarea bebas jalur kereta api \\
\hline R25 & Kecelakaan instalasi rel dan bantalan aktivitas diarea bebas jalur kereta api. \\
\hline R26 & Kerusakan semboyan utilitas exsisting selama aktivitas proyek. \\
\hline $\mathrm{R} 27$ & Kecelakaan kendaraan umum diperlintasan sebidang diarea proyek. \\
\hline \multirow[t]{2}{*}{$\mathrm{R} 28$} & Kerusakan lingkungan proyek yang bersingungan dengan aktivitas proyek. \\
\hline & Pekerjaan Sipil/Pendukung Track \\
\hline R29 & Sulitnya koordinasi pekerjaan antar kontraktor. \\
\hline R30 & Kecelakaan karena pagar sterilisasi diperlintasan seidang terlalu tinggi. \\
\hline R31 & Kecelakaan pekerja proyek tidak menggunakan alat perlindung diri. \\
\hline R32 & Keterlambatan karena spesifikasi pekerjaan berubah-ubah. \\
\hline R33 & Pengadaan material dan peralatan yang tiadak tepat. \\
\hline R34 & Pengalihan lokasi pekerjaan karena volume material berlebih. \\
\hline \multirow[t]{2}{*}{ R35 } & Kurangnya koordinasi sesama konsultan \\
\hline & Pekerjaan Box Culvert \\
\hline R36 & Hilangnya peralatan dan material karena curah hujan yang tinggi. \\
\hline R37 & Rusaknya saluran perairan pertanian warga selama pengerjaan jembatan. \\
\hline R38 & Kurangnya perkuatan dan perawatan jembatan darurat. \\
\hline R39 & Kurangnya perkuatan penahan longsoran galian jembatan. \\
\hline
\end{tabular}

\subsection{Analisis Risiko}

Risiko membentuk efek kumulatif pada satu atau lebih aspek proyek dan lebih mudah untuk memitigasi peristiwa risiko jika mereka dapat dikelompokkan dalam dan sebaiknya ditangani pada tingkat yang lebih tinggi dalam jangka panjang dari pada berfokus pada satu peristiwa risiko tertentu, di mana kasus proyek mungkin dikelola secara mikro.

Identifikasi risiko dilakukan dengan melakukan brainstorming dan interview dengan pihak yang memiliki kompetensi terhadap risiko. Selanjutnya menyebarkan draft kuisoner kepada para narasumber untuk validasi item-item variabel penelitian. Item-item pertanyaan kuesioner yang sudah dijawab oleh para narasumber kemudian dilanjutkan dilanjutkan dengan uji validitas dan reliabilitas kuesioner menggunakan Software SPSS v23. Hasil uji validitas dan reliabilitas memungkinkan ada beberapa item yang perlu digugurkan atau dimodifikasi, sedemikian sehingga draft kuesioner tersebut telah absah (valid dan reliabel) menjadi kuesioner dan dapat digunakan sebagai instrumen penelitian manajemen risiko untuk disebarkan (disurveykan) kembali kepada para responden sejumlah 25 orang yang memiliki pengalaman lebih dari 5 tahun dalam proyek pembangunan jalur kereta api. Hasil jawaban dari responden terhadap kemungkinan dan konsekwensi terjadinya risiko dijelaskan pada Tabel 2 dan 3 sebagai berikut: 


\section{Applied Industrial Engineering Journal}

Vol.02, No. 01, Juni 2018, pp. 08 15

ISSN 2614-235X (Printed)

ISSN 2615-3033 (Online)

http://publikasi.dinus.ac.id/index.php/aiej/index

Tabel 2. Hasil Jawaban Reponden Terhadap Kemungkinan Terjadinya Risiko

\begin{tabular}{|l|c|c|c|}
\hline \multicolumn{1}{|c|}{ Likelihood } & $\mathrm{f}$ & Nomor Risiko & $\%$ \\
\hline 1. Frekuensi skala 1 (sangat jarang) & 3 & $\mathrm{R}, 17,25,34$ & 7.69 \\
\hline 2. Frekuensi skala 2 (jarang) & 15 & $\mathrm{R}, 6,9,10,12,14,15,16,22,26,28,29,30,31,35,36$ & 38.46 \\
\hline 3. Frekuensi skala 3 (kadang-kadang) & 3 & $\mathrm{R}, 17,25,34$ & 5.13 \\
\hline 4. Frekuensi skala 4 (sering) & 13 & $\mathrm{R}, 1,2,4,11,13,19,20,21,23,27,32,38,39$ & 35.90 \\
\hline 5. Frekuensi skala 5 (sangat sering) & 5 & $\mathrm{R}, 3,5,7,8,18$ & 12.82 \\
\hline \multicolumn{1}{|c|}{ Jumlah } & 39 & & 100 \\
\hline
\end{tabular}

Tabel 3. Hasil Jawaban Reponden Terhadap Konsekwensi Risiko

\begin{tabular}{|l|c|c|c|}
\hline \multicolumn{1}{|c|}{ Konsekwensi } & $\mathrm{f}$ & Nomor Risiko & $\%$ \\
\hline 1. Konsekuensi skala 1 (sangat kecil) & 1 & $\mathrm{R}, 22$ & 2.56 \\
\hline 2. Konsekuensi skala 2 (kecil) & 10 & $\mathrm{R}, 1,2,7,17,20,26,28,29,31,35$ & 25.64 \\
\hline 3. Konsekuensi skala 3 (sedang) & 8 & $\mathrm{R}, 3,4,8,11,12,18,34,36$ & 20.51 \\
\hline 4. Konsekuensi skala 4 (besar) & 15 & $\mathrm{R}, 5,6,13,14,16,21,23,24,25,27,30,33$ & 38.46 \\
\hline 5. Konsekuensi skala 5 (sangat besar) & 5 & $\mathrm{R}, 9,10,15,19,32$ & 12.82 \\
\hline \multicolumn{1}{|c|}{ Jumlah } & 39 & & 100 \\
\hline
\end{tabular}

\subsection{Penilaian Risiko (Assessment Risk)}

Penilaian risiko pada dasarnya adalah melakukan perhitungan atau penilaian terhadap dampak risiko yang telah teridentifikasi, besar kecilnya dampak risiko akan dapat dikategorikan, mana merupakan risiko dengan tingkat yang utama (major risks), yang mempunyai dampak besar dan luas yang membutuhkan pengelolaan, atau tidak (minor risks), yang tidak memerlukan penanganan khusus karena tingkat risiko ada dalam batas-batas yang dapat diterima. Menguraikan besarnya dampak risiko merupakan perkalian dari frekuensi (likelihood) dengan konsekuensi (consequence) dari risiko yang telah teridentifikasi[8]. Berdasarkan hasil perkalian tersebut diperoleh nilai risiko untuk dapat menentukan tingkat penerimaan risiko (acceptability of risk). Tindakan mitigasi dilakukan untuk risiko-risiko yang termasuk dalam kategori tidak dapat diterima (unacceptable). Hasil penerimaan risiko dapat dijelaskan pada Tabel 4 dan 5 sebagai berikut:

Tabel 4. Hasil Penerimaan Risiko (Acceptability Of Risk)

\begin{tabular}{|l|c|c|c|}
\hline \multicolumn{1}{|c|}{ Acceptability } & $\mathrm{f}$ & Nomor Resiko & $\%$ \\
\hline 1. Unacceptable (tidak dapat diterima) & 12 & $\mathrm{R}, 3,5,8,13,18,19,21,23,27,32,38,39$ & 30.77 \\
\hline 2. Undesirable (tidak diharapkan) & 19 & $\mathrm{R}, 1,2,4,6,7,9,10,11,12,14,15,16,17,20,25,30,33,34,36$ & 48.72 \\
\hline 3. Acceptable (dapat diterima) & 7 & $\mathrm{R}, 24,26,28,29,31,35,37$ & 17.95 \\
\hline 4. Negligible (dapat diabaikan) & 1 & $\mathrm{R}, 22$ & 2.56 \\
\hline \multicolumn{1}{|c|}{ Jumlah } & 39 & & 100 \\
\hline
\end{tabular}




\section{Applied Industrial Engineering Journal}

Vol.02, No. 01, Juni 2018, pp. 08 15

ISSN 2614-235X (Printed)

ISSN 2615-3033 (Online)

http://publikasi.dinus.ac.id/index.php/aiej/index

Tabel 5. Daftar Risiko Yang Tidak Dapat Diterima

\begin{tabular}{|c|l|c|c|c|}
\hline $\begin{array}{c}\text { No } \\
\text { Risiko }\end{array}$ & \multicolumn{1}{|c|}{ Daftar Resiko Proyek Jalur Ganda } & $\mathrm{KT}^{*}$ & $\mathrm{~K}^{*}$ & $\mathrm{AOR}^{*}$ \\
\hline R3 & Putusnya jaringan kabel persinyalan kereta api. & 5 & 3 & 15 \\
\hline R5 & Rusaknya peralatan pendukung keselamatan aktivitas proyek. & 5 & 4 & 15 \\
\hline R8 & $\begin{array}{l}\text { Kurangnya pengawasan aktivitas alat berat yang bersinggungan jalur } \\
\text { kereta }\end{array}$ & 5 & 3 & 15 \\
\hline R13 & Rusaknya fasilitas umum selama aktivitas proyek. & 4 & 4 & 16 \\
\hline R18 & $\begin{array}{l}\text { Sleeding galian tanah tubuh baan (new track/exsisting) tanah dasar tidak } \\
\text { stabil. }\end{array}$ & 5 & 3 & 15 \\
\hline R19 & Keterlambatan pekerjaan subkontraktor. & 4 & 5 & 20 \\
\hline R21 & Kegagalan pengelasan antar batang rel. & 4 & 4 & 16 \\
\hline R23 & Adanya perubahan desain elevasi dan center line tubuh baan & 4 & 4 & 16 \\
\hline R27 & Kecelakaan kendaraan diperlintasan sebidang area proyek. & 4 & 4 & 16 \\
\hline R32 & Keterlambatan pekerjaan karena spesifikasi berubah-rubah. & 4 & 5 & 20 \\
\hline R38 & Kurangnya perkuatan dan perawatan jembatan darurat. & 4 & 4 & 16 \\
\hline R39 & Kurangnya perkuatan penahan longsoran pembuatan jembatan & 4 & 4 & 16 \\
\hline
\end{tabular}

${ }^{\star} \mathrm{KT}=$ Kemungkinan Terjadi

${ }^{*} \mathrm{~K}=$ Konsekwensi

${ }^{*} \mathrm{AOF}=$ Acceptability of risk

\subsection{Respon Risiko (Risk Respon Planning)}

Penilaian risiko dilakukan dengan mengalikan kemungkinan (likelihood) dan pengaruh (consequences). Berdasarkan hasil perkalian tersebut diperoleh nilai risiko untuk dapat menentukan tingkat penerimaan risiko (acceptability of risk). Risiko-risiko yang termasuk dalam kategori risiko yang tidak dapat diterima (unacceptable) dan risiko yang masuk dalam kategori tidak diharapkan (undesirable) memerlukan adanya tindakan mitigasi untuk mengurangi dampak yang ditimbulkan. Tindakan-tindakan mitigasi yang dilakukan dalam penelitian ini didapatkan dari hasil analisis, wawancara dengan pihak yang berkompeten yang memiliki tanggung jawab terhadap terjadinya risiko untuk dapat dilakukan tindakan mitigasi agar dapat mengurangi dampak negatif yang ditimbulkan.Tindakan mitigasi risiko dijelaskan pada Tabel 6 sebagai berikut:

Tabel 6. Mitigasi Risiko Yang Tidak Bisa Diterima

\begin{tabular}{|c|c|c|}
\hline $\begin{array}{c}\text { No } \\
\text { Risiko }\end{array}$ & \multicolumn{1}{|c|}{ Daftar Risiko Proyek Jalur Ganda Kereta Api } & \multicolumn{1}{c|}{ Mitigasi Risiko } \\
\hline R3 & Putusnya jaringan kabel persinyalan kereta api. & $\begin{array}{l}\text { Melakukan koordinasi dengan pihak } \\
\text { persinyalan untuk perbaikan jaringan } \\
\text { kabel sinyal KA dan meminta } \\
\text { pendampingan/pengawasan pekerjan } \\
\text { atau melakukan penggalian manual } \\
\text { terdahulu. }\end{array}$ \\
\hline R5 & $\begin{array}{l}\text { Remberikan tugas kepada train watcher } \\
\text { kesaknya peralatan pendukung kesehatan dan } \\
\text { keselamatan kerja. }\end{array}$ & $\begin{array}{l}\text { sebelum memulakukan pengecekan } \\
\text { meninggalkan lokasi pekerjaan serta } \\
\text { segera melakukan perbaikan peralatan } \\
\text { pendukung keselamatan kerja. }\end{array}$ \\
\hline
\end{tabular}




\section{Applied Industrial Engineering Journal}

Vol.02, No. 01, Juni 2018, pp. 08 15

ISSN 2614-235X (Printed)

ISSN 2615-3033 (Online)

http://publikasi.dinus.ac.id/index.php/aiej/index

\section{Lanjutan Tabel 6. Mitigasi Risiko Yang Tidak Bisa Diterima}

\begin{tabular}{|c|c|c|}
\hline R8 & $\begin{array}{l}\text { Kurangnya pengawasan aktivitas alat berat yang } \\
\text { bersinggungan jalur kereta }\end{array}$ & $\begin{array}{l}\text { Mengadakan pelatihan singkat kepada } \\
\text { operator tentang keselamatan kerja dan } \\
\text { menambah train watcher untuk } \\
\text { melakukan pengawasan setiap aktifitas } \\
\text { alat berat. }\end{array}$ \\
\hline $\mathrm{R} 13$ & Rusaknya fasilitas umum selama aktivitas proyek. & $\begin{array}{l}\text { Memperbaiki fasilitas umum yang } \\
\text { bersingungan dengan proyek dan } \\
\text { melakukan perawatan rutin selama } \\
\text { aktifitas proyek. }\end{array}$ \\
\hline $\mathrm{R} 18$ & $\begin{array}{l}\text { Sleeding galian tanah tubuh baan (new } \\
\text { track/exsisting) tanah dasar tidak stabil. }\end{array}$ & $\begin{array}{l}\text { Melakukan pekerjaan di saat perjalanan } \\
\text { KA tidak padat (windows time) dan tidak } \\
\text { meninggalkan galian terbuka disekitaran } \\
\text { perlintasan kereta. }\end{array}$ \\
\hline $\mathrm{R} 19$ & Keterlambatan pekerjaan subkontraktor. & $\begin{array}{l}\text { Memberikan pemantauan dan } \\
\text { peringatan kepada subkontraktor yang } \\
\text { terlambat atau menambah } \\
\text { subkontraktor. }\end{array}$ \\
\hline $\mathrm{R} 21$ & Kegagalan pengelasan antar batang rel. & $\begin{array}{l}\text { Melakukan pengawasan terhadap } \\
\text { pemasangan rel dan aksesoris dengan } \\
\text { tidak memberikan jarak antra rel yang } \\
\text { akan dilakukan pengelasan. }\end{array}$ \\
\hline $\mathrm{R} 23$ & $\begin{array}{l}\text { Adanya perubahan desain elevasi dan center line } \\
\text { tubuh baan }\end{array}$ & $\begin{array}{l}\text { Mengecek ulang kesesuaian gambar } \\
\text { kerja dengan kondisi lapangan dan } \\
\text { melakukan koordinasi dengan konsultan } \\
\text { perencana. }\end{array}$ \\
\hline $\mathrm{R} 27$ & $\begin{array}{l}\text { Kecelakaan kendaraan umum diperlintasan } \\
\text { sebidang area proyek. }\end{array}$ & $\begin{array}{l}\text { Pembuatan palang pintu perlintasan } \\
\text { sementara, penjagaan perlintasan dari } \\
\text { kedua belah sisi perlintasan. }\end{array}$ \\
\hline R32 & $\begin{array}{l}\text { Keterlambatan karena spesifikasi pekerjaan } \\
\text { berubah-rubah. }\end{array}$ & $\begin{array}{l}\text { Melakukan koordinasi dengan konsultan } \\
\text { perencana dan memastikan semua } \\
\text { spesifikasi pekerjaan yang akan di } \\
\text { kerjakan. }\end{array}$ \\
\hline R38 & $\begin{array}{l}\text { Kurangnya perkuatan dan perawatan jembatan } \\
\text { darurat. }\end{array}$ & $\begin{array}{l}\text { Memperkuat jembatan darurat dan } \\
\text { melakukan perawatan berkala selama } \\
\text { proyek berlangsung. }\end{array}$ \\
\hline R39 & $\begin{array}{l}\text { Kurangnya perkuatan penahan longsoran galian } \\
\text { jembatan }\end{array}$ & $\begin{array}{l}\text { Meningkatkan kekuatan penahan } \\
\text { longsoran tanah dengan menggunakan } \\
\text { site pile }\end{array}$ \\
\hline
\end{tabular}

\section{Kesimpulan}

Hasil penelitian proyek pembangunan proyek jalur ganda kereta api risiko yang teridentifikasi sebanyak 39 (tiga puluh sembilan risiko) memiliki risiko yang cukup tinggi karena langsung bersingungan dengan jalur kereta aktif sehingga dapat teridentifikasi untuk risiko yang tidak diharapkan sebanyak 19 risiko. Selain itu risiko yang tidak dapat diterima sebanyak 12 risiko. Risiko yang tidak dapat diterima memerlukan mitigasi risiko mengurangi dampak yang ditimbulkan.

Adapun saran terhadap penelitian dan analisis yang telah dilakukan terhadap kontraktor atau perusahaan adalah dapat menerapan manajemen risiko sejak awal proyek itu dimulai dan selalu meningkatkan fungsi manajemen risiko kemudian dijadikan sebagai pedoman pelaksanaan proyek sehingga penerapannya dapat meningkatkan kesehatan dan keselamatan kerja dan meningkatkan kualitas dari perusahaan. 


\section{Applied Industrial Engineering Journal}

Vol.02, No. 01, Juni 2018, pp. 08 15

ISSN 2614-235X (Printed)

ISSN 2615-3033 (Online)

http://publikasi.dinus.ac.id/index.php/aiej/index

\section{Referensi}

[1] Serpella, A.F., Ferrada X., Howard R., Rubio L., 2013. Risk management in construction projects: a knowledge-based approach. Prodia-Social and Behavioral Sciences, 119 ( 2014 ), 653 - 662. www.sciencedirect.com

[2] Nasrul., 2015. Manajemen Risiko Dalam Proyek Konstruksi Ditinjau Dari Sisi Manajemen Waktu. Jurnal Momentum ISSN: 1693-752X. Institut Teknologi Padang .Vol.17 No.1. Februari 2015.

[3] Befrouei, M. A., Taghipour. Mohammad., 2015. Identification and Management of Risks in Construction Projects. American Journal of Civil Engineering. Vol. 3, No. 5, 2015, pp. 170-177. doi: 10.11648/j.ajce.20150305.15

[4] Kangari, R., (1995), Risk Management Prerseption and Trends of US Construction, Journal of Construction Engineering and Management, ASCE, Vol 121.

[5] Kerzner Harold, (2001). Project Management: A System to Planning, Scheduling and Controlling, (7th Edition, John Wiley \& Sons), hal. 3.

[6] Anonim. 2004. A Guide To The Project Management Body Of Knowledge Third Edition.

[7] Norken, I.N., Astana, I.N.Y., dan Manuasri, L.K.A. 2012. Manajemen Risiko pada Proyek Konstruksi di Pemkab Jembrana. Fakultas Teknik Sipil Universitas Udayana Denpasar.

[8] Godfrey, P.S., Sir William Halcrow and Partners Ltd. 1996. Control of Risk A Guide to Systematic Management Of Risk from Construction. Wesminster London : Construction Industry Research and Information Association (CIRIA). 